\title{
Global Spatial Analyses of Phylogenetic Conservation Priorities for Aquatic Mammals
}

\author{
Laura J. May-Collado, Carlos Zambrana-Torrelio, and Ingi Agnarsson
}

\begin{abstract}
Several studies have shown how current climate change and human threats to aquatic environments are significantly impacting aquatic mammals worldwide. In response to these threats it is important to prioritize conservation efforts. A recent approach to evaluate conservation priorities is to combine information on species status from the International Union for Conservation of Nature (IUCN) Red List with information on the evolutionary history of the species from phylogenetic trees. This new approach provides a measure of biodiversity that complements estimates of species richness, adding evolutionary distinctiveness of species. Using near-complete species level phylogenies for the mammal groups with aquatic species (Carnivora, Cetacea, Sirenia) we calculated two measures (EDGE and HEDGE) of conservation priorities for 127 aquatic mammals under two scenarios of projected extinctions: a "pessimistic" approach, which represents a "worst case scenario' for each species; and the "IUCN 50" a projected extinction risk over the next 50 years (Table 1). Then we analyzed the information to identify conservation priority areas (CPA) for aquatic mammals. We identified 22 CPAs distributed primarily along coastal waters in both northern and southern hemispheres. While thousands of marine protected areas (MPA) have been established in recent years, only $11.5 \%$ of CPAs overlap with existing MPAs. Nevertheless, all phylogenetic CPAs identified in this study have also been proposed to be important by other independent studies using different prioritization criteria, highlighting the importance of focusing conservation efforts in these areas.
\end{abstract}

Keywords $\mathrm{IUCN} \bullet$ Cetaceans $\bullet$ Pinnipeds $\bullet$ Manatees $\bullet$ EDGE $\bullet$ HEDGE

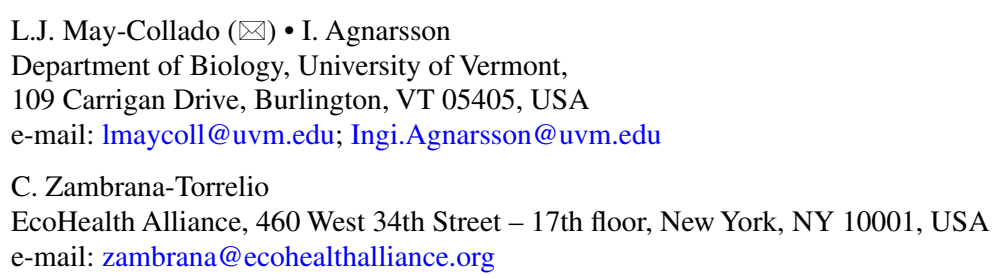




\section{Introduction}

Current climate change and human threats to aquatic environments are significantly impacting aquatic mammals worldwide (Schipper et al. 2008; Davidson et al. 2011; Harnik et al. 2012; Harkonen et al. 2012). A recent study showed that $74 \%$ of aquatic mammals experience high levels of human impact within their geographic range, with pollution and fisheries being the two most important threats (Davidson et al. 2011). Human overexploitation is proposed as the major cause of extinction of the Steller's sea cow (Hydrodamalis gigas), the tropical monk seal (Monachus tropicalis) (Hofman 1995) and more recently the Yangtze river dolphin or Baiji (Lipotes vexillifer) (Turvey et al. 2007). Also brought to the brink of extinction have been three additional aquatic mammals: the vaquita (Phocoena sinus) and the Hawaiian and Mediterranean monk seals (Monachus schauinslandi and M. monachus) whose populations have been reduced to fewer than 250 individuals (IUCN 2013.2). Some $28 \%$ of aquatic mammals are threatened or near threatened under the International Union for Conservation of Nature (IUCN) risk classification and an additional $39 \%$ are data deficient leaving only $33 \%$ of aquatic mammal species at low risk. Furthermore, recent studies have suggested that even some of these species at relatively low risk should receive conservation attention due to their high evolutionary distinctiveness (May-Collado and Agnarsson 2011) and possible sudden changes in their risk of extinction due to rapidly changing environment (Davidson et al. 2011). Examples of such evolutionarily unique species are the data deficient Amazon River dolphin (Inia geoffrensis) and the walrus (Odobenus rosmarus). Both species are the only extant representatives of old lineages and live in habitats threatened by human activities and climate change, respectively. Additionally, based on the IUCN population trend information we estimate that most aquatic mammals are either decreasing $(19.3 \%)$ or unknown $(64.3 \%)$. In the light of these threats it is important to prioritize conservation efforts. In 2011, the Convention on Biological Diversity put in place a plan to protect $10 \%$ of the world's marine and coastal ecological regions by 2020 . Thus identifying geographic areas that could maximize these conservation goals is an urgent task (Davidson et al. 2011).

The International Union Conservation of Nature (IUCN) is the most influential conservation network in the world. Through its 'Red List' the IUCN has established conservation priorities prominently based on the imperilment levels of individual species. These categorizations are used by a number of organizations and government agencies to prioritize funding and conservation efforts. IUCN levels of imperilment result from the combination of several criteria including population size, evidence of population decline or recovery, distribution patterns and factors threatening species (http://www.iucn.org).

However, there are other criteria to establish conservation priorities including the use of 'umbrella species' also known as keystone or flagship species (Zacharias and Roff 2001), 'sentinel species' (Moore 2008), 'latent extinction risk' (Cardillo et al. 2006), regional and local habitat models (e.g., Praca et al. 2009; Azzellino et al. 2012), and identification of hot-spots of species richness (Davidson et al. 2011; Kaschner et al. 2011; Pompa et al. 2011). Recent approaches to identify conservation priorities combine information on species status from the IUCN with information 
on the evolutionary history of the species from phylogenetic trees (Faith 1992, 2002, 2008; Faith et al. 2004; Redding and Mooers 2006; Schipper et al. 2008; Isaac et al. 2007; Mooers et al. 2008; Kuntner et al. 2009; Agnarsson et al. 2010; May-Collado and Agnarsson 2011). This new approach to conservation provides a measure of biodiversity that complements estimates of species richness, that is, of evolutionary distinctiveness of species. The fundamental argument is that the loss of evolutionarily unique species lacking close relatives represents a greater loss of biodiversity than the loss of species whose evolutionary history is, to a great extent, preserved in other closely related species (May-Collado and Agnarsson 2011).

Considering both evolutionary histories of lineages and species' threats can help the goal of maximizing biodiversity conservation. This approach of identifying areas protecting both threatened species and containing high phylogenetic diversity provides another tool for decision-making. Here we examine global patterns of aquatic mammal phylogenetic conservation priorities using four recently proposed metrics for 127 aquatic mammals. We identify Conservation Priority Areas (CPAs), estimate the degree to which such areas are contained within current Marine Protected Areas (MPA), and suggest areas where focusing future conservation effort might be particularly valuable.

\section{Material and Methods}

We used the most detailed primary-data species-level phylogenies available for the three major mammalian groups containing aquatic species Cetacea (May-Collado and Agnarsson 2006; May-Collado et al. 2007), Carnivora (Agnarsson et al. 2010), and Afrotheria (Kuntner et al. 2009). The conservation status for 127 aquatic mammals was obtained from the IUCN Red List of Threatened Species database (2010.4-2013.2) and transformed to probability estimates of extinction risk using two of the methods discussed in Mooers et al. (2008) "pessimistic" and "IUCN50". The "pessimistic" method is an arbitrary transformation that designates a sizable probability of extinction to every category. So, even for the 'least concern' species has a probability of 0.2 , which is much higher than in the IUCN 50 scenario (see Table 1) (Mooers et al. 2008). The "IUCN50" is a projection of extinction risk over the next 50 years given current conservation status, proposed by the IUCN. This scenario assumes that species in the 'least concern' category are essentially 'safe', assigning to them low probability of extinction (Mooers et al. 2008) (Table 1). We selected these two transformation methods because they offer contrasting scenarios based on how they treat species that are currently thought to be at relatively low risk.

Using these transformation methods we calculated conservation priority measures using the TUATARA module version 1.01 (Maddison and Mooers 2007) in the evolutionary analysis package MESQUITE version 2.75 (Maddison and Maddison 2011). We used the conservation priority methods EDGE (Evolutionary Distinct, Globally Endangered) (http://www.edgeofexistence.org), which measures evolutionary distinctiveness (ED) weighted by current IUCN levels of extinction risk. EDGE scores are equivalent to a logarithmic transformation of the product of 
Table 1 Extinction probabilities for IUCN levels of imperilment transformed into extinction probabilities using "pessimistic" and IUCN 50 transformations, as proposed by

Mooers et al. 2008

\begin{tabular}{|c|c|c|}
\hline IUCN level of imperilment & Pessimistic & IUCN 50 \\
\hline Least concern ${ }^{\mathrm{a}}$ & 0.2 & 0.0001 \\
\hline Data deficient ${ }^{\mathrm{b}}$ & 0.3 & 0.005 \\
\hline Near threatened ${ }^{\mathrm{a}}$ & 0.4 & 0.01 \\
\hline Vulnerable $^{\mathrm{a}}$ & 0.8 & 0.1 \\
\hline Endangered $^{\mathrm{a}}$ & 0.9 & 0.667 \\
\hline Critically endangered $^{\mathrm{a}}$ & 0.99 & 0.999 \\
\hline
\end{tabular}

${ }^{\mathrm{a}}$ Mooers et al. 2008

${ }^{\mathrm{b}}$ May-Collado and Agnarsson 2011

a species' evolutionary distinctiveness and the probability it will go extinct (see Isaac et al. 2007). We also use the conservation priority method HEDGE (Heightened EDGE), which like EDGE measure evolutionary distinctiveness by IUCN levels of extinction but additionally considers how future extinction of species will affect the evolutionary distinctiveness of remaining species. In sum, HEDGE estimates the expected terminal branch length of the focal species in light of future extinction risk (Steel et al. 2007). Both conservation methods generate fixed probabilities of extinction as described in Table 1. For more information on how IUCN levels of imperilments are transformed into probabilities of extinction see Moores et al. (2008). Because there are not estimated probabilities of extinction available for data deficient species we arbitrarily assigned an extinction risk score in between the two lowest IUCN extinction categories: least concern and near threatened (Table 1). All four metrics were calculated using both 'raw' branch lengths (estimated by MrBayes) as they contain information on the unique evolutionary information of terminal taxa and ultrametrized trees. Furthermore, with the purpose of comparing this approach to identify conservation priority areas with other commonly used conservation prioritization criteria we calculated evolutionary distinctiveness (ED) (Isaac et al. 2007) also implemented in the TUATARA module and gathered information on species richness.

To identify conservation priority areas (CPAs) we used distribution range maps from the IUCN spatial database (2013) as a baseline to produce species richness, ED, EDGE and HEDGE maps, under both IUCN extinction probabilities transformation methods, pessimistic and IUCN50. The IUCN spatial database depict species' range distribution as polygons based on the extent of occurrence, which is defined as the area contained within a minimum convex hull around species' observations or records. This convex hull or polygon is further improved by including areas known to be suitable or by removing unsuitable or unoccupied areas based on expert knowledge.

For each species the distribution range was converted to a grid system with cells of $5^{\prime} \times 5^{\prime}$ (approximately $10 \times 10 \mathrm{~km}$ at the Equator line). This spatial resolution was selected for its practical compromise between intensive computing and a reasonable representation of geographic patterns. Traditionally, a one-degree cell $(100 \times 100 \mathrm{~km})$ has been used in macroecological analyses, but there is no ecological reason behind 
the resolution. More importantly, it has been shown that higher spatial resolutions distort the geographical patterns of species richness (Rahbek 2005; Graham and Hijmans 2006). In contrast, lower spatial resolutions minimize the overestimation of distribution ranges, in particular of those species with small range distributions. For example, Rondinini et al. (2011) used a resolution of $300 \times 300 \mathrm{~m}$ for their estimations of global mammal' species richness.

Specie's presence in each $5^{\prime} \times 5^{\prime}$ grid cell was assigned with a value of one. The same procedure was repeated to assign the estimated values of ED, EDGE and HEDGE to the grid cells of each species' occurrence, and maps were calculated by overlying individual grids. For example, the species richness map represents the sum of all presence grids. Under this spatial framework CPAs represent areas with the highest scores due to a high number of species regardless of ED, EDGE, and HEDGE scores or to a few species with high probability scores.

To understand how well these patterns of aquatic mammal conservation priorities are already included in existing MPAs, we used information from the World Database on Protected Areas website (http://protectedplanet.net/). We calculated the percentage of each species range within all designated MPAs of the world and to preserve areal relationships we first re-projected both the species ranges and the MPAs, to an equal area using Behrmann projection. We then iteratively intersected each marine species range with all the MPAs using the function joinPolys with the operator 'INT' (intersection) from the package PBS-Mapping (version 2.67). Species range percentage within all MPAs was calculated by contrasting the sum of their intersected areas with the total species range area. All analyses were performed in $\mathrm{R}$ (R Core Team 2013) and the final maps were created using ArcGIS v10.1.

\section{Results}

Aquatic mammal species richness and the sum of species evolutionary uniqueness peaked in coastal waters of both northern and southern hemispheres. Both metrics showed high scores at the coasts of California and Japan in the northern hemisphere, and along the coast of Peru, Argentina, Uruguay, Southern Brazil, South Africa, Southern Australia, Tasmania, and New Zealand in the southern hemisphere (Fig. 1).

All methods identified the Hawaiian, Kurl, and Aleutian Islands, the coastal waters of northern California, Nouadhibou, Yangtze River, southern Brazil to Argentina, where both metrics had the highest cumulative scores in Rio de la Plata, and Southern Australia and Japan as CPAs (Figs. 2 and 3). Furthermore, the Mediterranean Sea was identified as other CPA under pessimistic EDGE and IUCN 50 HEDGE (Fig. 2a, d); South Africa, Patagonia, New Zealand, Tasmania, Bay of Bengal, Arabian Sea, Indonesia, and South China Sea under pessimistic HEDGE (Fig. 2b); and North Atlantic Ocean and Galapagos Islands, under IUCN50 EDGE (Fig. 2c). Figure 3 summarizes these four conservation priority metrics into a single map showing all CPAs. In each of them we highlight examples of top ranking phylogenetic conservation priority species (Table 2). 

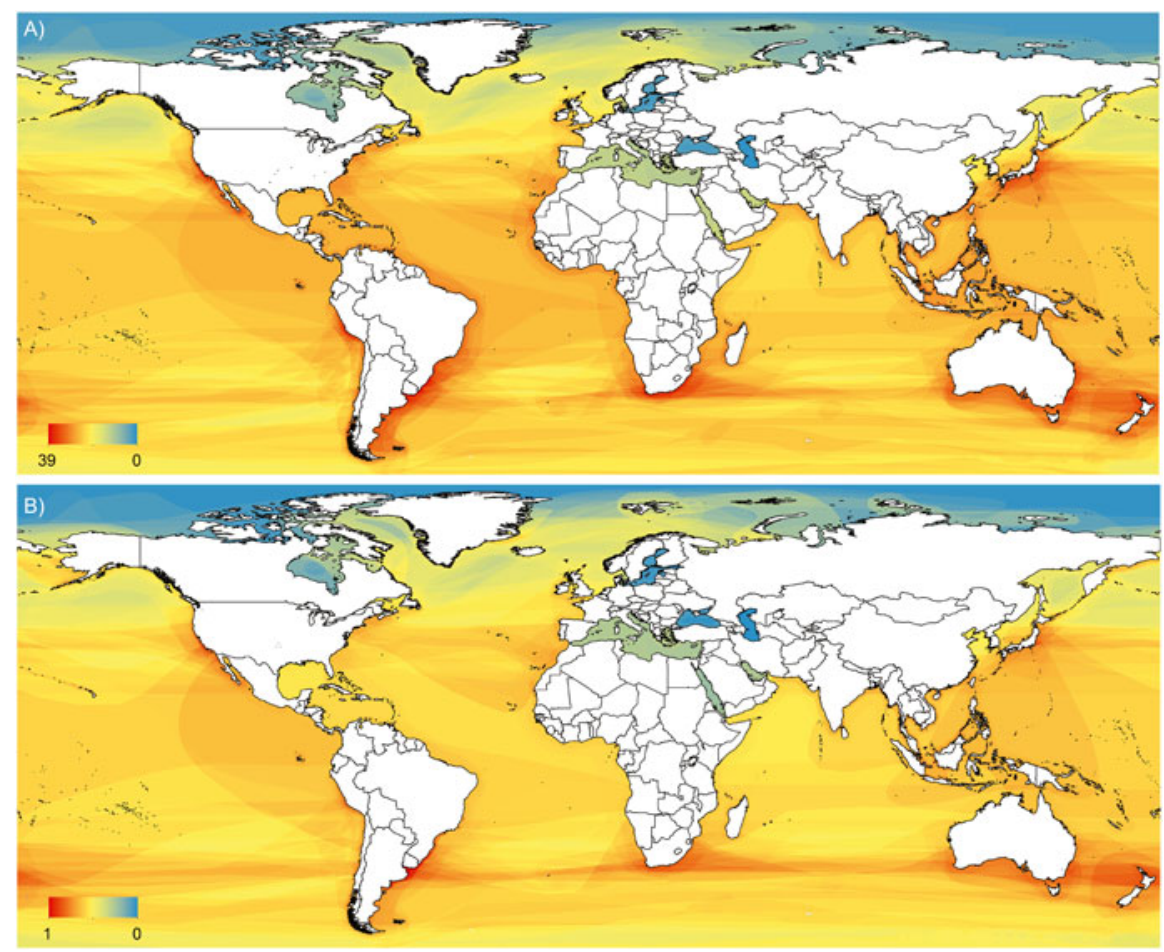

Fig. 1 Global patterns of aquatic mammal (a) species richness and (b) evolutionary distinctiveness (ED) (red tones represent the highest scores, cold colors indicate the lowest ones)

When we analyzed the overlap with designated marine protected areas we found that although there are 847 of MPAs, most are very small $\left(\right.$ mean $=201 \mathrm{~km}^{2}$; $\left.\mathrm{sd}=424 \mathrm{~km}^{2}\right)$ when compared to the average size of the CPAs $\left(2,269,520 \mathrm{~km}^{2}\right.$, $\mathrm{sd}=4,313,740 \mathrm{~km}^{2}$ ). Nearly $50 \%$ of large MPAs (those MPAs with an area greater than $500 \mathrm{~km}^{2}$ ) do not over overlap with any CPAs failing to protect important areas of aquatic mammal diversity as identified in this study (Fig. 4). Table 2 provides information on the \% overlap of top ranking phylogenetic conservation priority species (see highlighted species in Fig. 3) distribution that is under any form of protected area. With the exception of the Galapagos sea lion and fur seal and the Hawaiian monk seal most top conservation priority species habitat is unprotected.

\section{Discussion}

Here we provide the first spatial analysis of phylogenetic conservation priorities for aquatic mammals. We consider four methods that essentially reflect two possible scenarios differing in how extinction risk is evaluated for the lower threat categories and data deficient species: the pessimistic approach and the IUCN50 approach. The two approaches give dramatically different results, in many cases highlighting 

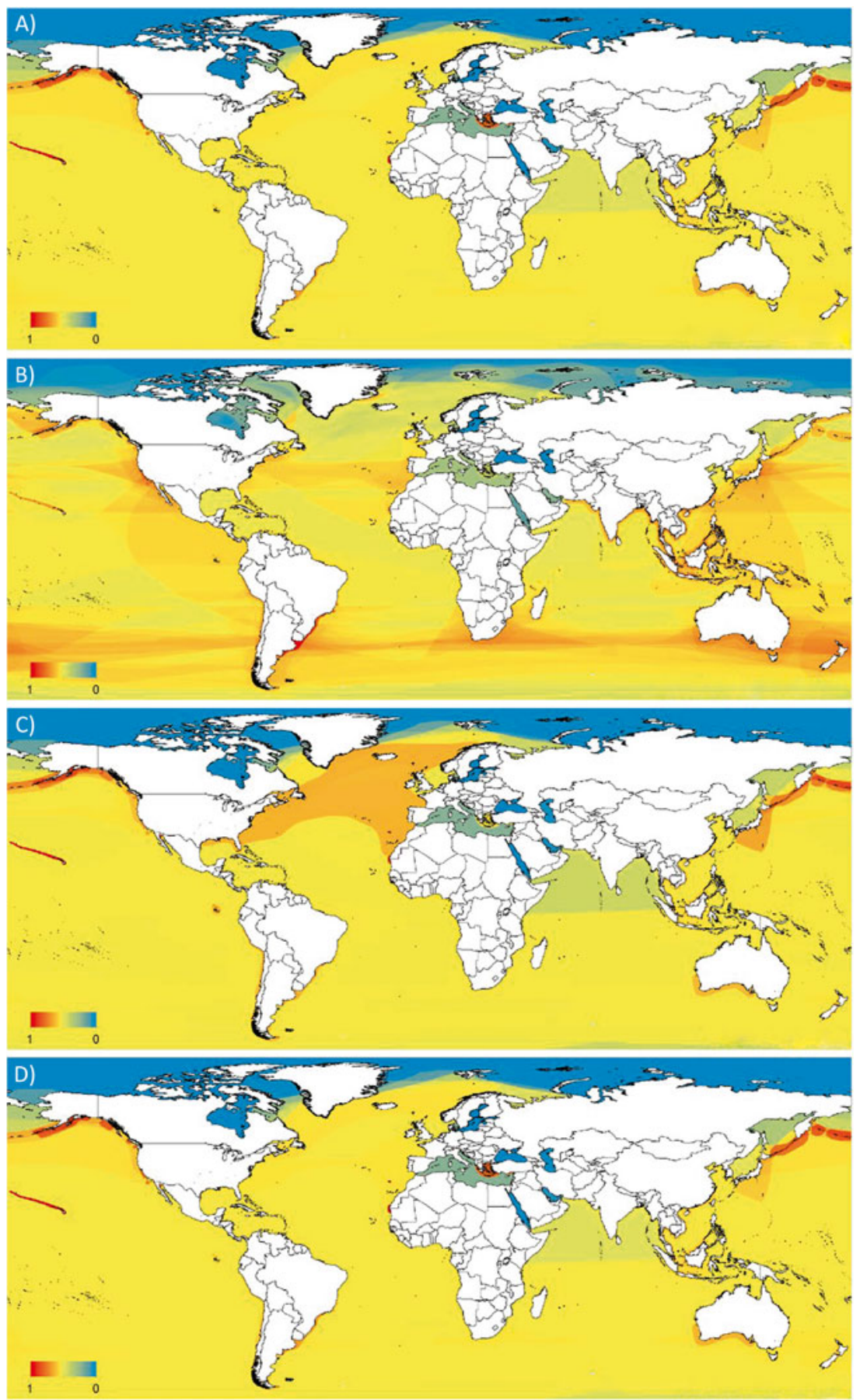

Fig. 2 Global patterns of conservation priorities using the conservation priority methods: (a) EDGE Pessimistic, (b) HEDGE Pessimistic, (c) EDGE IUCN 50 and (d) HEDGE IUCN 50 (red tones represent the highest scores, cold colors indicate the lowest ones) 


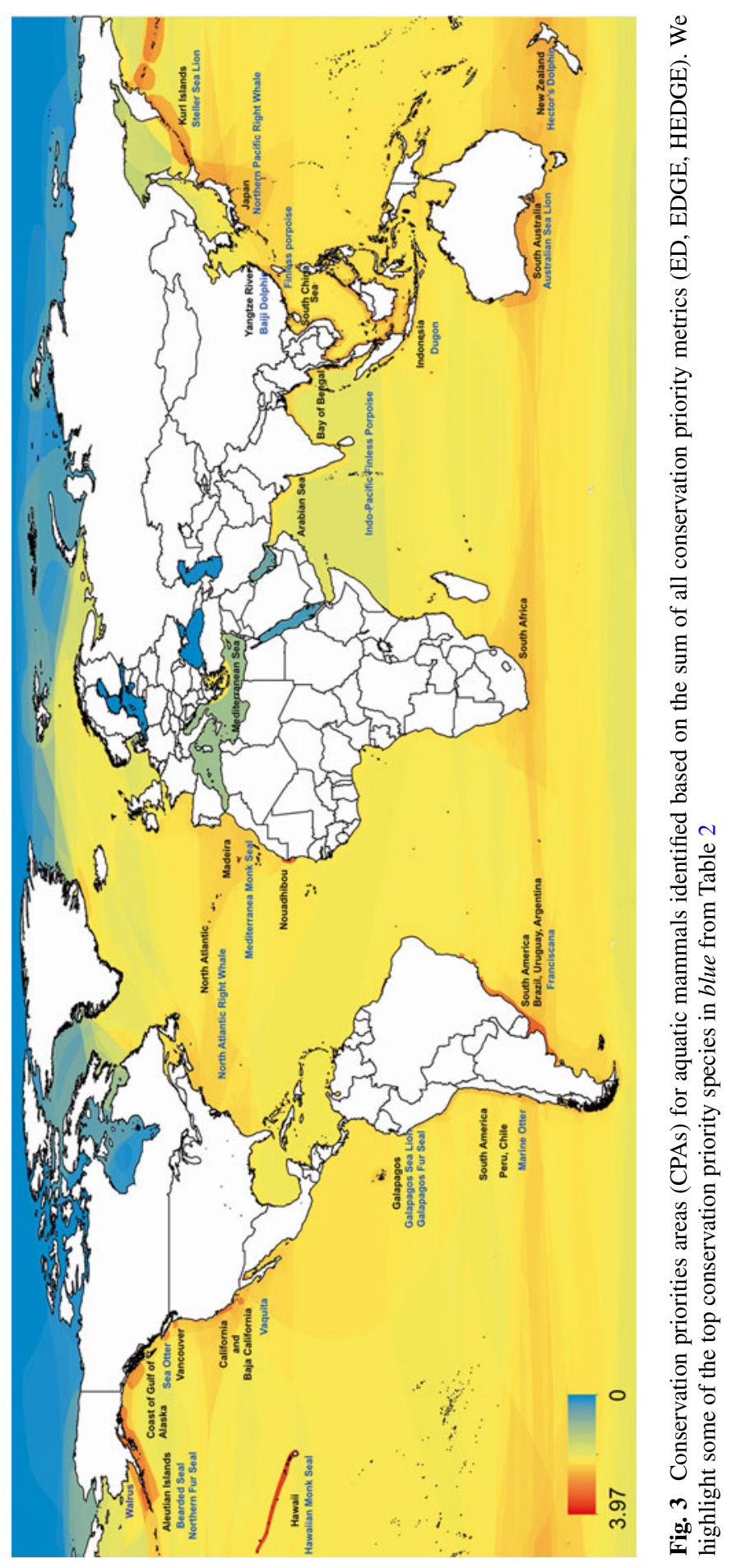


Table 2 Examples of aquatic mammal species that ranked among the top species for one or all methods, their corresponding conservation priority areas (CPAs), population status, and overall overlap with marine protected areas (MPAs)

\begin{tabular}{|c|c|c|c|c|}
\hline Species & IUCN value & $\begin{array}{l}\text { Population } \\
\text { trend }\end{array}$ & $\begin{array}{l}\text { Conservation } \\
\text { priority area }\end{array}$ & $\begin{array}{l}\text { Overlap of species } \\
\text { range and MPAs }(\%)\end{array}$ \\
\hline \multicolumn{5}{|l|}{ Cetaceans } \\
\hline Lipotes vexillifer & \multirow{2}{*}{$\begin{array}{l}\text { Critically } \\
\text { endangered }\end{array}$} & \multirow[t]{2}{*}{ Unknown } & \multirow[t]{2}{*}{ Yangtze River } & \multirow[t]{2}{*}{$<1 \%$} \\
\hline Baiji & & & & \\
\hline Pontoporia blainvillei & \multirow[t]{2}{*}{ Vulnerable } & \multirow[t]{2}{*}{ Unknown } & South America & \multirow[t]{2}{*}{$<1 \%$} \\
\hline Franciscana & & & $\begin{array}{l}\text { Brazil to } \\
\text { Argentina }\end{array}$ & \\
\hline $\begin{array}{l}\text { Neophocaena } \\
\text { asiaeorientalis and } N . \\
\text { phocaenoides }\end{array}$ & \multirow[t]{2}{*}{ Vulnerable } & \multirow[t]{2}{*}{ Decreasing } & \multirow{2}{*}{$\begin{array}{l}\text { Japan, East and } \\
\text { South China Sea, } \\
\text { Bay of Bengal, } \\
\text { Arabian Sea }\end{array}$} & \multirow[t]{2}{*}{$\begin{array}{l}\text { Not in } \\
\text { database } / 2.35 \% \\
\text { respectively }\end{array}$} \\
\hline Finless porpoises & & & & \\
\hline Phocoena sinus & \multirow{2}{*}{$\begin{array}{l}\text { Critically } \\
\text { endangered }\end{array}$} & \multirow[t]{2}{*}{ Decreasing } & \multirow[t]{2}{*}{ Baja California } & \multirow[t]{2}{*}{$33.6 \%$} \\
\hline Vaquita & & & & \\
\hline $\begin{array}{l}\text { Cephalorhynchus } \\
\text { hectori }\end{array}$ & \multirow[t]{2}{*}{ Endangered } & \multirow[t]{2}{*}{ Decreasing } & \multirow[t]{2}{*}{ New Zealand } & \multirow[t]{2}{*}{$<1 \%$} \\
\hline Hector's Dolphin & & & & \\
\hline Eubalaena glacialis & \multirow{2}{*}{ Endangered } & \multirow[t]{2}{*}{ Unknown } & \multirow{2}{*}{$\begin{array}{l}\text { North Atlantic } \\
\text { Ocean }\end{array}$} & \multirow[t]{2}{*}{$<1 \%$} \\
\hline $\begin{array}{l}\text { North Atlantic Right } \\
\text { Whale }\end{array}$ & & & & \\
\hline Eubalaena japonica & \multirow[t]{2}{*}{ Endangered } & \multirow[t]{2}{*}{ Unknown } & \multirow[t]{2}{*}{ Japan } & \multirow[t]{2}{*}{$<1 \%$} \\
\hline $\begin{array}{l}\text { North Pacific Right } \\
\text { Whale }\end{array}$ & & & & \\
\hline \multicolumn{5}{|l|}{ Pinnipeds } \\
\hline $\begin{array}{l}\text { Monachus } \\
\text { schauinslandi }\end{array}$ & \multirow[t]{2}{*}{$\begin{array}{l}\text { Critically } \\
\text { endangered }\end{array}$} & \multirow[t]{2}{*}{ Decreasing } & \multirow[t]{2}{*}{ Hawaii } & $69.1 \%$ \\
\hline Hawaiian Monk Seal & & & & \\
\hline Monachus monachus & Critically & Decreasing & Mediterranean & $4.54 \%$ \\
\hline $\begin{array}{l}\text { Mediterranean Monk } \\
\text { Seal }\end{array}$ & endangered & & $\begin{array}{l}\text { Sea, Madeira, } \\
\text { Nouadhibou }\end{array}$ & \\
\hline Enhydra lutris & Endangered & Decreasing & Gulf of Alaska, & $6.9 \%$ \\
\hline Sea Otter & & & California & \\
\hline Lontra felina & Endangered & Decreasing & South America & $12.4 \%$ \\
\hline Marine Otter & & & Peru and Chile & \\
\hline Callorhinus ursinus & Vulnerable & Decreasing & Kurl and & $1.6 \%$ \\
\hline Northern Fur Seal & & & $\begin{array}{l}\text { Aleutian Islands, } \\
\text { Gulf of Alaska, } \\
\text { California }\end{array}$ & \\
\hline Eumetopias jubatus & & Increasing & Kurl and & $3.8 \%$ \\
\hline Steller Sea Lion & threatened & & $\begin{array}{l}\text { Aleutian Islands, } \\
\text { Gulf of Alaska, } \\
\text { California }\end{array}$ & \\
\hline
\end{tabular}


Table 2 (continued)

\begin{tabular}{|c|c|c|c|c|}
\hline Species & IUCN value & $\begin{array}{l}\text { Population } \\
\text { trend }\end{array}$ & $\begin{array}{l}\text { Conservation } \\
\text { priority area }\end{array}$ & $\begin{array}{l}\text { Overlap of species } \\
\text { range and MPAs (\%) }\end{array}$ \\
\hline Neophoca cinerea & \multirow[t]{2}{*}{ Endangered } & \multirow[t]{2}{*}{ Decreasing } & \multirow{2}{*}{$\begin{array}{l}\text { Southern } \\
\text { Australia }\end{array}$} & \multirow[t]{2}{*}{$6.4 \%$} \\
\hline Australian Sea Lion & & & & \\
\hline Zalophus wollebaeki & \multirow[t]{2}{*}{ Endangered } & \multirow[t]{2}{*}{ Decreasing } & \multirow[t]{2}{*}{ Galapagos Island } & \multirow[t]{2}{*}{$60.2 \%$} \\
\hline Galapagos Sea Lion & & & & \\
\hline Odobenus rosmarus & \multirow{2}{*}{$\begin{array}{l}\text { Data } \\
\text { deficient }\end{array}$} & \multirow[t]{2}{*}{ Unknown } & \multirow[t]{2}{*}{ Aleutian Islands } & \multirow[t]{2}{*}{$6.86 \%$} \\
\hline Walrus & & & & \\
\hline $\begin{array}{l}\text { Arctocephalus } \\
\text { galapagoensis }\end{array}$ & \multirow[t]{2}{*}{ Endangered } & \multirow[t]{2}{*}{ Decreasing } & \multirow[t]{2}{*}{ Galapagos Island } & \multirow[t]{2}{*}{$99.5 \%$} \\
\hline Galapagos Fur Seal & & & & \\
\hline Erignathus barbatus & \multirow{2}{*}{$\begin{array}{l}\text { Least } \\
\text { concern }\end{array}$} & \multirow[t]{2}{*}{ Stable } & \multirow[t]{2}{*}{ Aleutian Islands } & \multirow[t]{2}{*}{$3.4 \%$} \\
\hline Bearded seal & & & & \\
\hline
\end{tabular}

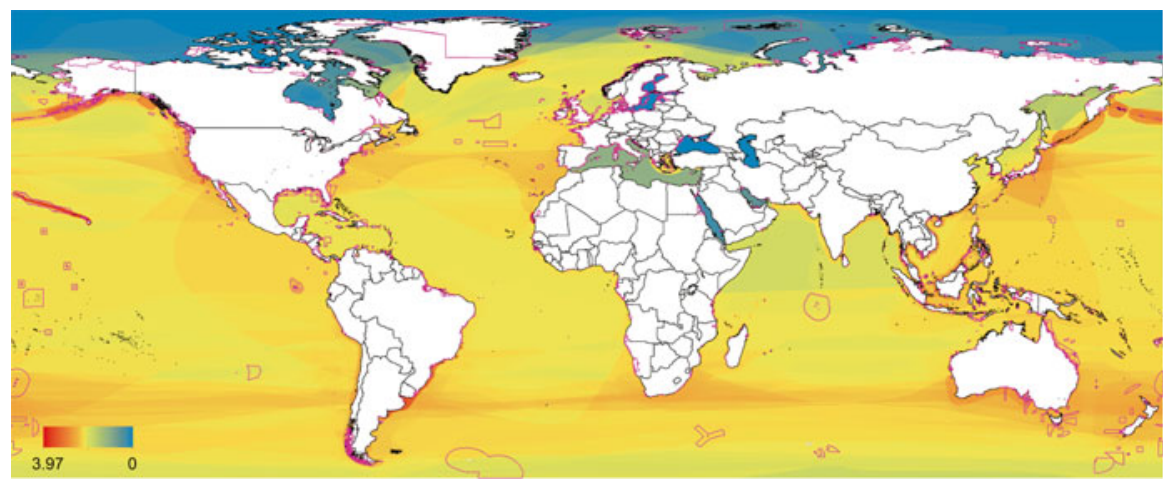

Fig. 4 Overlap of conservation priority areas (CPAs) and global distribution of designated marine protected areas (MPAs) (in pink). Lower panels highlight those CPAs with low spatial overlap with MPAs

different CPAs. The pessimistic approach gives more weight to phylogenetic diversity, while the IUCN50 gives more weight to extinction risk of species (MayCollado and Agnarsson 2011). Given that both perspectives are valid, we used a combination of these two scenarios to identify Conservation Priority Areas, emerging as highly ranking under one or both of these approaches (see Fig. 3). These results provide a tool for conservation planning for aquatic mammals that supplements previous spatial studies using other prioritization criteria (Davidson et al. 2011; Kashner et al. 2011; Pompa et al. 2011), and may thus be useful in helping to guide future conservation effort.

Our results indicate that accumulative evolutionary distinctiveness and conservation priorities are in general concentrated in coast waters. This pattern could be an artifact of survey effort in coastal waters and in general reflect that aquatic mammal 
survey coverage, whether coastal or oceanic, is very limited (Jewell et al. 2012). Less than $25 \%$ of the ocean surface has been surveyed and only $6 \%$ has been covered frequently enough to allow estimations of population trends (Kaschner et al. 2012). In addition, spatial coverage is also significantly biased towards some ocean basins. Karchner et al. (2012) reported that with the exception of Antarctic waters, survey coverage was biased toward the northern hemisphere, especially US and northern European waters, which may explain the consensus among methods identifying the Aleutian and Hawaiian Islands as CPAs. Nevertheless, despite this potential data bias most CPAs were found in the southern hemisphere, suggesting that phylogenetic conservation priority methods do not simply reflect sampling effort, but identify areas that contain aquatic mammal communities including both evolutionarily unique species and those at risk.

As we discussed in our methods, CPAs were the result from the cumulative values for each metric in each cell. Thus CPAs may reflect a large number of species varying in conservation priority values or possibly only a few species with high values. The later seems to be the case for Hawaii, Nouadhibou, Madeira Island, Yangtze river, and Southern Brazil-Argentina where highly evolutionary unique species are endemic to those areas (Table 2). Other CPAs such as California, Southern Australia and New Zealand include many species, but only some of which are evolutionarily unique species. These areas are part of ranges of several species with very broad distribution ranges such as the sperm whale, pygmy and dwarf sperm whales, and blue whale. Interestingly, previous studies that have used species richness to identify 'hotspot' of aquatic mammal diversity (Pompa et al. 2011) and a combination of levels of imperilment with intrinsic and extrinsic factors to identify high risk areas for aquatic mammals (Davidson et al. 2011) agree with the CPAs identified here. Davidson et al. (2011) identified five major global hotspots of marine mammal species at risk. Within these major hotpots several locations overlap with those found in this study: Aleutian Islands, Alaska, California, Galapagos, Patagonia, South Africa, Japan, Indonesia, South Australia, and New Zealand. Pompa et al. (2011) identified nine 'hotspots' based solely on species richness and 11 irreplaceable key conservation sites, based on the presence of endemic species, five of these sites Hawaiian and Galapagos Islands, Mediterranean Sea, and the Yangtze river network were also identified as CPAs. Finally, Kashner et al. (2011) using an environmental suitability model predicted highest marine mammal richness in New Zealand, Japan, Baja California, Galapagos, the Southeast Pacific and Southern Ocean, all congruent with our study.

Within the CPAs identified here we highlight the presence of several top ranking conservation priority species among those are the extant monk seals (see Table 2). The UICN has estimated a $68 \%$ reduction of Hawaiian monk seal abundance in the past 49 years, and projects an $86 \%$ reduction in the next 15 years. The future for the Mediterranean monk seal seems bleak, current population estimates are about 350450 individuals (IUCN 2013). The Cap Blanc population in Nouadhibou is probably the most threatened, with less than 220 individuals. This is the last population with colonial structure, so its loss would also lead to the loss of a peculiar behavior amongst monk seals (e.g., Gonzalez 2006; Martinez-Jauregui et al. 2012; Gonzalez 
and Fernandez de Larrinoa 2013). Both species are facing fragmentation of their habitat that overlaps with a number of human activities, some of which affects them directly as bycatch in gillnets and bottom trawl nets particularly in the case of the Mediterranean monk seal (Gonzalez and Fernandez de Larrinoa 2013). In 1988 Hawaiian monk seal habitats were declared as 'critical areas' by the Endangered Species Act, limiting several federally authorized activities such permits for fishing, coastal development, and a number of military activities. However, the designation of critical habitat offers limited protection, allowing a number of non-federal activities such as boating and jet-skiing, and tour operations that might have an indirect impact in their recovery. For the Mediterranean monk seals, surveyed protected marine areas might help mitigate interactions with fisheries (Rowwe 2007). Despite growing efforts in protecting the species, only $4.5 \%$ of their habitat is currently protected. In areas where it is protected such as in Madeira Island, Portugal the creation of a natural reserve and change in fishing gear has halted monk seal decline and helped their recovery (Pires et al. 2008; Hale et al. 2011) but such protected area is not in place in Nouadhibou yet (Gonzalez and Fernandez de Larrinoa 2013).

For cetaceans we would like to highlight the river dolphin Baiji and the coastal Franciscana. The Baiji dolphin is likely extinct, no sightings of the species have been made in recent years. In 2005, its population size was estimated to be less than 100 individuals (Dudgeon 2005). A number of restoration efforts have been made including establishing of natural and seminatural reserves in the middle and lower parts of the Yangtze River, and breeding programs. However, the extent of the human impact on this species habitat may not allow its recovery with $\sim 5 \%$ of the world's total population living along the Yangtze River (Yang et al. 2006). In contrast with the Baiji, the Franciscana is population size is considered 'healthy' by the IUCN. However, the extent of bycatch mortality by nearshore gillnets in southern Brazil results in thousands of individuals killed every year, this is a major reason for concern (Danilewicz et al. 2010; Prado et al. 2013), particularly when less than $1 \%$ of the species habitat is under protection. Current MPAs within the species range are few, most are small, sparse, and outside the Rio del Plata area where conservation priority values peaked. Conservation priorities species such as the Hector's dolphins in New Zealand and finless porpoises (see Figs. 3 and 4) may benefit from expansion of local MPAs, which currently protect only a small percent of their habitat. In contrast, conservation priority species with global distribution such as sperm, blue, sei and fin whales, may benefit for a multinational management approach at the species level combined with protected areas in key breeding and feeding grounds.

Our results offer a spatial phylogeny-based conservation prioritization for aquatic mammals that complements prior findings. Given urgent need to invest management and conservation efforts and the Convention on Biological Diversity plan to protect $10 \%$ of the world's marine and coastal ecological regions by 2020 , such analyses should be helpful tools in identifying important areas for consideration.

Acknowledgements We thank EcoHealth Alliance for providing us with the resources to produce the spatial analysis and to Lisa Ballance, Roseli Pellens, and an anonymous reviewer for their comments that greatly improve this manuscript. 
Open Access This chapter is distributed under the terms of the Creative Commons AttributionNoncommercial 2.5 License (http://creativecommons.org/licenses/by-nc/2.5/) which permits any noncommercial use, distribution, and reproduction in any medium, provided the original author(s) and source are credited.

The images or other third party material in this chapter are included in the work's Creative Commons license, unless indicated otherwise in the credit line; if such material is not included in the work's Creative Commons license and the respective action is not permitted by statutory regulation, users will need to obtain permission from the license holder to duplicate, adapt or reproduce the material.

\section{References}

Agnarsson I, Kuntner M, May-Collado LJ (2010) Dogs, cats, and kin: a molecular species-level phylogeny of Carnivora. Mol Phylogenet Evol 54:726-745

Azzellino A, Panigada S, Lanfredi C et al (2012) Predictive habitat models for managing marine areas: spatial and temporal distribution of marine mammals within the Pelagos Sanctuary (Northwestern Mediterranean sea). Ocean Coast Manag 67:63-74

Cardillo M, Mace GM, Gittleman JL, Purvis A (2006) Latent extinction risk and the future battlegrounds of mammal conservation. Proc Natl Acad Sci U S A 103:4157-4161

Danilewicz D, Moreno IB, Ott PH et al (2010) Abundance estimate for a threatened population of franciscana dolphins in southern coastal Brazil: uncertainties and management implications. J Mar Biol Assoc UK 90:1-9

Davidson AD, Boyer AG, Kim H et al (2011) Drivers and hotspots of extinction risk in marine mammals. Proc Natl Acad Sci U S A 109:3395-3400

Dudgeon D (2005) Last chance to see: ex situ conservation and the fate of the baiji. Aquat Conserv Mar Freshw Ecosyst 15:105-108

Faith DP (1992) Conservation evaluation and phylogenetic diversity. Biol Conserve 61:1-10

Faith DP (2002) Quantifying biodiversity: a phylogenetic perspective. Conserv Biol 16:248-252

Faith DP (2008) Threatened species and the potential loss of phylogenetic diversity: conservation scenarios based on estimated extinction probabilities and phylogenetic risk analysis. Conserv Biol 22:1461-1470

Faith DP, Reid CAM, Hunter J (2004) Integrating phylogenetic diversity, complementarity, and endemism for conservation assessment. Conserv Biol 18:255-261

González LM (2006) The action plan for the recovery of the Mediterranean monk seal in the Eastern Atlantic. O.A. Parques Nacionales. Ministerio de Medio Ambiente, Madrid, pp 290

González LM, Fernández de Larrinoa P (2013) Mediterranean monk seal Monachus monachus distribution and fisheries interactions in the Atlantic Sahara during the second half of the 20th century. Mammalia 77:41-49

Graham CH, Hijmans RJ (2006) A comparison of methods for mapping species ranges and species richness. Global Ecol Biogeogr 15:578-587

Hale R, Pires R, Santos P, Karamanlidis A (2011) Mediterranean monk seal (Monachus monachus): fishery interactions in the Archipelago of Madeira. Aquat Mamm 37:298-304

Harkonen T, Harding KC, Wilson S et al (2012) Collapse of a marine mammal species driven by human impacts. PLoS One 7:e43130

Harnik PG, Lotze HK, Anderson SC et al (2012) Extinctions in ancient and modern seas. Trends Ecol Evol 27:608-617

Hofman RJ (1995) The changing focus of marine mammal conservation. Trends Ecol Evol $10: 462-464$

Isaac NJB, Turvey ST, Collen B et al (2007) Mammals on the EDGE: conservation priorities based on threat and phylogeny. PLoS One 2:e296 
Jewell R, Thomas L, Harris CM et al (2012) Global analysis of cetacean line-transect surveys: detecting trends in cetacean density. Mar Ecol Prog Ser 453:227-240

Kashner K, Tittensor DP, Ready J et al (2011) Current and future patterns of global marine mammal biodiversity. PLoS One 6:e19653

Kashner K, Quick NJ, Jewell R et al (2012) Global coverage of cetacean line-transect surveys: status quo, data gaps, and future challenges. PLoS One 7:e44075

Kuntner M, May-Collado LJ, Agnarsson I (2009) Phylogeny and conservation priorities of afrotherian mammals (Afrotheria, Mammalia). Zool Scr 40:1-15

Maddison WP, Maddison DR (2011) Mesquite: a modular system for evolutionary analysis. Version 2.75. Available via http://mesquiteproject.org

Maddison WP, Mooers AØ (2007) Tuatara: conservation priority in a phylogenetic context, Version 1.0. Available: http://mesquiteproject.org/packages/tuatara

Martínez-Jaúregui M, Tavecchia G, Cedenilla MA et al (2012) Population resilience of the Mediterranean monk seal Monachus monachus at Cabo Blanco peninsula. Mar Ecol Prog Ser 461:273-281

May-Collado LJ, Agnarsson I (2006) Cytochrome b and Bayesian inference of whale phylogeny. Mol Phylogenet Evol 38:344-354

May-Collado LJ, Agnarsson I (2011) Phylogenetic analysis of conservation priorities for aquatic mammals and their terrestrial relatives, with a comparison of methods. PLoS One 6(7):e22562

May-Collado LJ, Agnarsson I, Wartzok D (2007) Phylogenetic review of tonal sound production in whales in relation to sociality. BMC Evol Biol 7:136

Mooers A, Faith DP, Maddison WP (2008) Converting endangered species categories to probabilities of extinction for phylogenetic conservation prioritization. PLoS ONE 3:e3700

Moore SE (2008) Marine mammals as ecosystem sentinels. J Mammal 89:534-540

Pires R, Costa Neves N, Karamanlidis A (2008) The critically endangered Mediterranean monk seal Monachus monachus in the archipelago of Madeira: priorities for conservation. Oryx 42:278-285

Pompa S, Ehrlich P, Ceballos G (2011) Global distribution and conservation of marine mammals. Proc Natl Acad Sci U S A 108:13600-13605

Praca E, Gannier A, Das K, Laran S (2009) Modelling the habitat suitability of cetaceans: example of the sperm whale of the northwestern Mediterranean Sea. Deep Sea Res I 56:648-657

Prado JHF, Secchi ER, Kinas PG (2013) Mark-recapture of the endangered franciscana dolphin (Pontoporia blainvillei) killed in gillnet fisheries to estimate past bycatch from time series of stranded carcasses in southern Brazil. Ecol Indic 32:35-41

R Core Team (2013) R: a language and environment for statistical computing. R Foundation for Statistical Computing, Vienna

Rahbek C (2005) The role of spatial scale and the perception of large-scale species-richness patterns. Ecol Lett 8:224-239

Redding DW, Mooers AØ (2006) Incorporating evolutionary measures into conservation prioritization. Conserv Biol 20:1670-1678

Rondinini C, Di Marco M, Chiozza F et al (2011) Global habitat suitability models of terrestrial mammals. Philos Trans R Soc Lond B Biol Sci 366:2633-2641

Rowwe SJ (2007) A review of methodologies for mitigating incidental catch of protected marine mammals. DOC research \& development series 283. Science \& Technical Publishing, New Zealand Department of Conservation, Wellington

Schipper J, Chanson J, Chiozza F et al (2008) The status of the world's land and marine mammals: diversity, threat, and knowledge. Science 322:225-230

Steel M, Mimoto A, Mooers AØ (2007) Hedging one's bets: quantifying a taxon's expected contribution to future phylogenetic diversity. Evol Bioinform 3:237-244

The IUCN Red List of Threatened Species (2013). http://www.iucnredlist.org

Turvey ST, Pitman RL, Taylor BL et al (2007) First human-caused extinction of a cetacean species? Biol Lett 3:537-540

Yang G, Bruford MW, Wei F, Zhou K (2006) Conservation options for the Baiji: time for realism? Conserv Biol 20:620-622

Zacharias MA, Roff JC (2001) Use of focal species in marine conservation and management: a review and critique. Aquat Conserv Mar Freshw Ecosyst 11:59-76 